\title{
Two new species of the family Linyphiidae from the Himalayas (Arachnida: Aranei) ${ }^{1}$
}

\author{
Ава новых вида семейства Linyphiidae из Гималаев \\ (Arachnida: Aranei)
}

\begin{abstract}
A.V. Tanasevitch
A.B. Танасевич

A.N. Severtsov Institute of Ecology and Evolution, Russian Academy of Sciences, Leninsky prospekt 33, Moscow 119071, Russia. E-mail: tanasevitch@gmail.com

Институт проблем экологии и эволюции им. А.Н. Северцова РАН, Ленинский проспект 33, Москва 119071, Россия.
\end{abstract}

KEYWORDS: taxonomy, spiders, Agyneta, Erigone, Asia, India, Nepal, mountains.

КЛЮЧЕВЫЕ СЛОВА: таксономия, пауки, Agyneta, Erigone, Азия, Индия, Непал, горы.

ABSTRACT. Two new species of the family Linyphiidae are described from the Himalayas: Agyneta himalaya sp.n. from Nepal and Erigone jammu sp.n. from India. The new Agyneta Hull, 1911 seems to be most similar to the Siberian arcto-boreo-montane $A$. ripariensis Tanasevitch, 1984, and to the Nepalense $A$. jiriensis Wunderlich, 1983. The new Erigone Audouin, 1826 resembles the Palaearctic arcto-alpine E. remota L. Koch, 1869 and the nival E. lata Song et Li, 2008, the latter species described from the Hengduan Mts, China. Both new species are clearly distinguished from their most similar congeners by the structural details of the genitalia.

How to cite this article: Tanasevitch A.V. 2018. Two new species of the family Linyphiidae from the Himalayas (Arachnida: Aranei) // Arthropoda Selecta. Vol.27. No.3. P.239-243. doi: 10.15298/arthsel. 27.3.08

РЕЗЮМЕ. Из Гималаев описаны два новых вида пауков семейства Linyphiidae: Agyneta himalaya sp.n. из Непала и Erigone jammu sp.n. из Индии. Новый вид Agyneta Hull, 1911 близок к сибирскому арктоборео-монтанному A. ripariensis Tanasevitch, 1984 и непальскому A. jiriensis Wunderlich, 1983. Новый вид Erigone Audouin, 1826 имеет явные черты сходства с палеарктическим аркто-альпийским E. remota L. Koch, 1869 и нивальным E. lata Song et Li, 2008, описанному из Сино-Тибетских гор, Китай. Оба новых вида хорошо отличаются от наиболее близких представителей своего рода деталями строения гениталий.

\section{Introduction}

At present, six and five species of the genera Agyneta Hull, 1911 and Erigone Audouin, 1826, respectively, have been recorded from the Himalayas: A. bueko
Wunderlich, 1983, A. jiriensis Wunderlich, 1983, A. pseudofuscipalpis Wunderlich, 1983 and A. yulungiensis Wunderlich, 1983 from Nepal [Wunderlich, 1983]; A. pakistanica Tanasevitch, 2011 and A. nigripes (Simon, 1884) from Pakistan [Tanasevitch, 2011]. All these species, except $A$. nigripes, have originally been described from the Himalayas. Erigone dentipalpis (Wider, 1834) is known from Karakorum, Pakistan [Caporiacco, 1935] and Kashmir, India [O. Pickard-Cambridge, 1885]; E. nepalensis Wunderlich, 1983 from Nepal [Wunderlich, 1983]; E. prominens Bösenberg et Strand, 1906 from Nepal [Wunderlich, 1983, referred to as E. ourania Crosby et Bishop, 1928] and Pakistan [Tanasevitch, 2011]; E. rohtangensis Tikader, 1981 from Himachal Pradesh, India [Tikader, 1981]. Erigone pseudovagans Caporiacco, 1935, from Karakorum [Caporiacco, 1935], will be synonymized elsewhere [Tanasevitch, in preparation].

\section{Material and methods}

This paper is based on the spider material taken by J. Martens and W. Schawaller in India and Nepal, kept in the Senckenberg Museum, Frankfurt am Main, Germany (SMF). The sample number is given in square brackets. All specimens are preserved in $70 \%$ ethanol and studied using a MBS-9 stereo microscope. A Levenhuk C-800 digital camera was applied for taking some photographs. Images taken at multiple focal planes were combined with the help of Helicon Focus image stacking software, version 5.1. The sequence of leg segment measurements is as follows: femur + patella + tibia + metatarsus + tarsus. All measurements are given in millimeters. The chaetotaxy is given in a formula, e.g., 2.2.2.1, which refers to the number of dorsal spines on tibiae I-IV. Scale lines in the figures correspond to

Results of the Himalaya Expeditions of J. Martens, No. 283 - J.M. sponsored by Deutscher Akademischer Austauschdienst and Deutsche Forschungsgemeinschaft. 

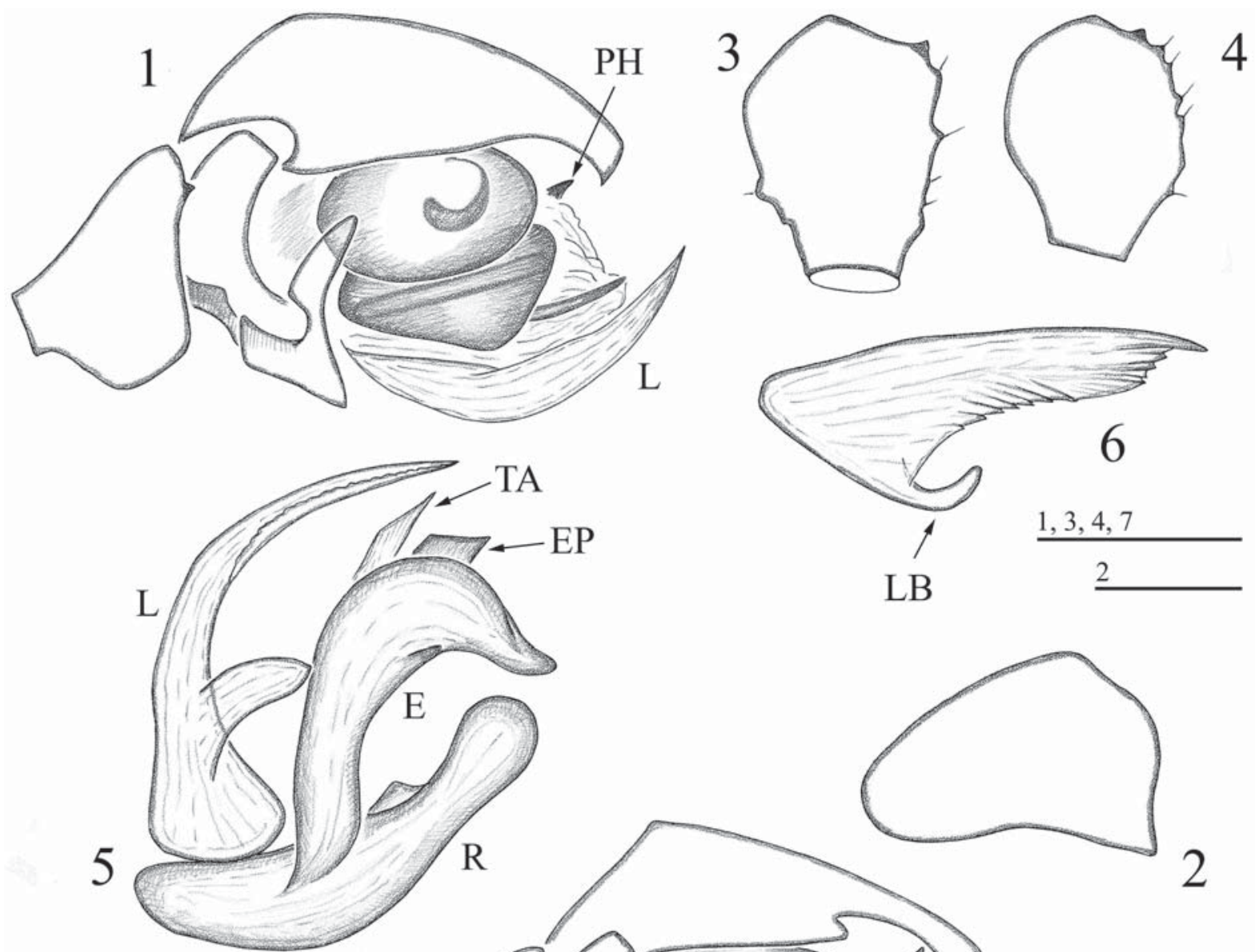

EP

LB

2

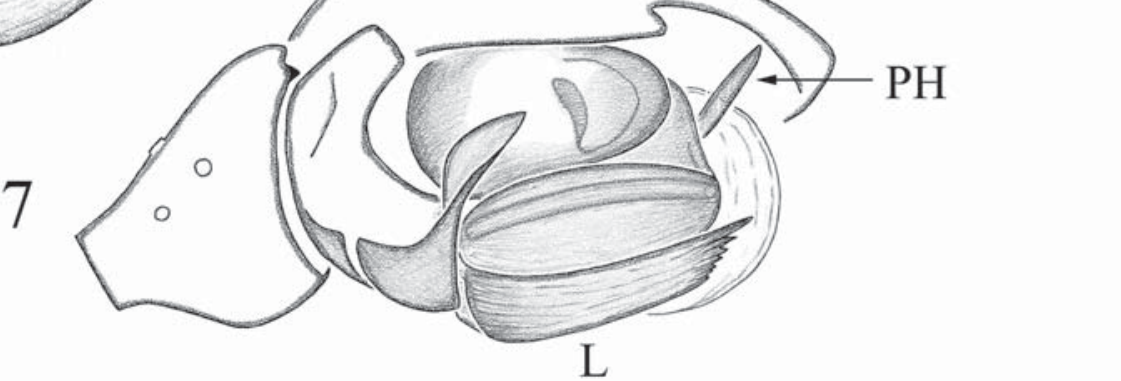

Figs 1-7. Details of palpal structure of Agyneta himalaya sp.n., paratype (1-6), holotype (7). 1,7 - right palp: lamella characteristica in Fig. 1 slightly turned and displaced down, vs. that in Fig. 7 in normal position; 2 - cymbium, prolaterally; 3, 4 - tibia, dorsal views, different aspects; 5 - embolic division; 6 - lamella characteristica.

Рис. 1-7. Детали строения пальпы Agyneta himalaya sp.n., паратип (1-6), голотип (7). 1, 7 — правая пальпа: на Рис. 1 lamella characteristica слегка повёрнута и сдвинута вниз, на Рис. 7 lamella characteristica в нормальном положении; 2 - цимбиум, пролатерально; 3, 4 - голень, вид сверху, различные аспекты; 5 - эмболюсный отдел; 6 - lamella characteristica.

$0.1 \mathrm{~mm}$ unless indicated otherwise. The terminology of copulatory organs mainly follows that of Merrett [1963], Saaristo [1971, 1973], Saaristo \& Tanasevitch [1996], Tanasevitch [2017], etc.

The following abbreviations are used in the text and figures: a.s.l. - above sea level; Co - column; D — duct; DSA - distal suprategular apophysis sensu Hormiga [2000]; E - embolus; EM - embolic membrane sensu Tanasevitch [2017] not sensu van Helsdingen [1986] and Hormiga [1994]; EP — embolus proper sensu Saaristo [1971]; L — lamella characteristica; LB - lower branch of lamella characteristica; LE - lateral edge of epigyne; MeRT - mesal radical tooth of embolic division $=$ mesal tooth sensu Crosby \& Bishop [1928]; MM - median membrane sensu Helsdingen [1965] = embolic membrane sensu van Helsdingen [1986] and Hormiga [1994]; MRA — median radical apophysis of embolic division $=$ median tooth sensu Crosby \& Bishop [1928]; Mt — metatarsus; PH pit hook sensu Saaristo [1973]; PMP — posterior median plate sensu Helsdingen et al. [1977] = dorsal plate, median plate, central capsule, auct.; PRA posterior radical apophysis = posterior tooth sensu Crosby \& Bishop [1928]; R — radix; Re — receptacle; 

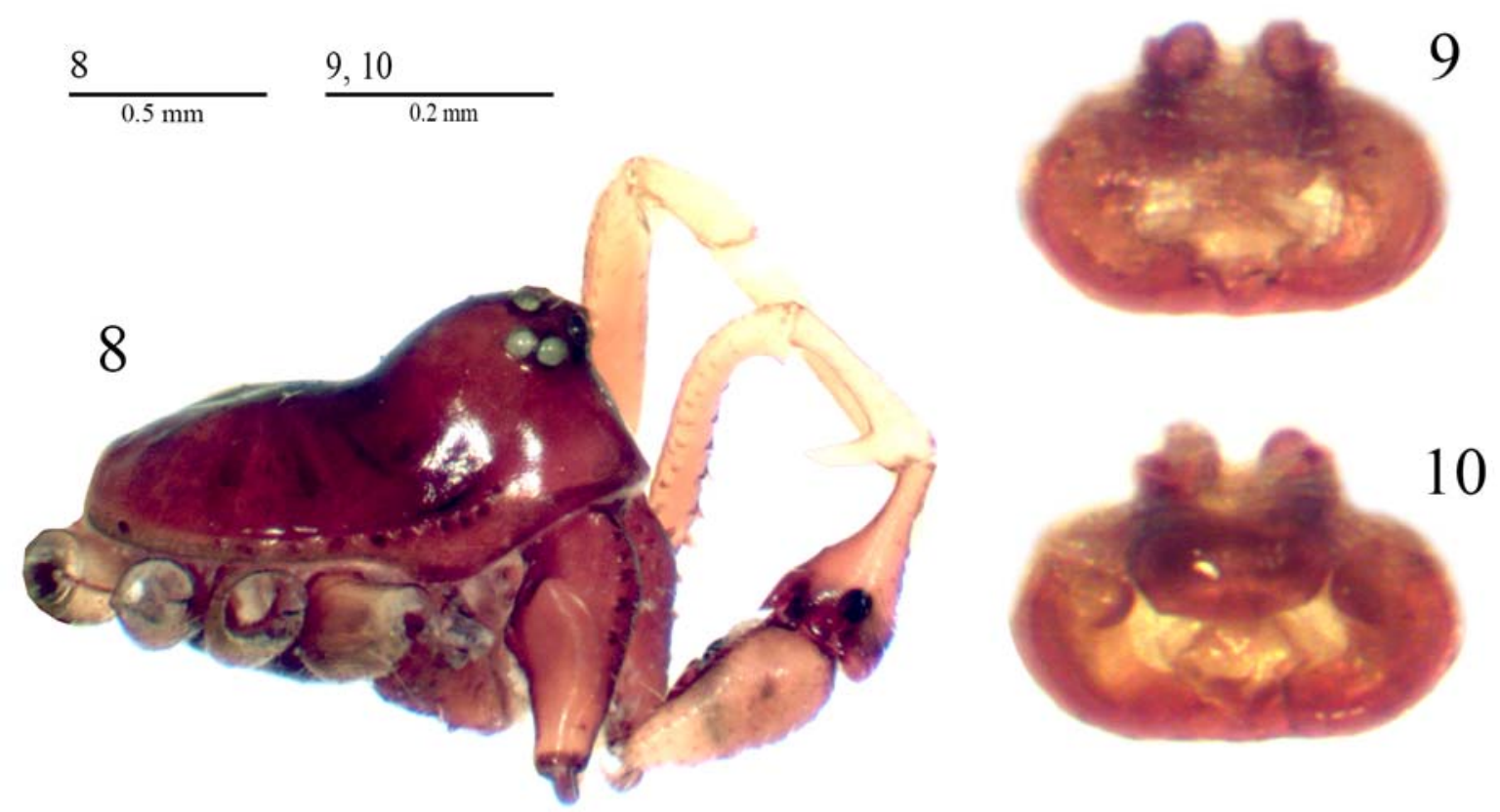

Figs 8-10. Photographs of male prosoma with left pedipalp $(8)$ and epigyne $(9,10)$ of Erigone jammu sp.n. 8-10 - lateral, ventral and dorsal views, respectively.

Рис. 8-10. Фотографии головогруди самца с левой педипальпой (8) и эпигины $(9,10)$ Erigone jaтmu sp.n. $8-10$ - вид сбоку, снизу и сверху, соответственно.

ReT - retrolateral tibial tooth; TmI - position of trichobothrium on metatarsus I.

\section{Descriptions}

\section{Agyneta himalaya sp.n.} Figs 1-7.

HOLOTYPE: Ơ (SMF), NEPAL, Panchthar District, Dhorpar Kharka, Rhododendron \& Lathocarpus forest, $2700 \mathrm{~m}$ a.s.1., 1316.IV.1988, leg. J. Martens \& W. Schawaller [No. 324].

PARATYPE: $1 \sigma^{7}$ (SMF), Taplejung District, Ladza Kharka in Ladza Khola NWof Walungchung Gola, 4100-4200 m a.s.1., dwarf Rhododendron, creeping Juniperus, 21-23.V.1988, leg. J. Martens \& W. Schawaller [No. 383].

TYPE MATERIAL EXAMINED. Agyneta jiriensis Wunderlich, 1983, holotype $\sigma^{7}$ (SMF, No. 31667). The type is now a fully faded male with a separated, almost transparent palp devoid of the embolic division.

NAME. The specific name is a noun in apposition, referring to provenance.

DIAGNOSIS. The palp of the new species seems to be most similar to that of the Nepalense $A$. jiriensis Wunderlich, 1983, which was described based on a single male from Jiri District, Nepal. Agyneta himalaya sp.n. differs by the shape of the lamella characteristica and the presence of a short additional branch beginning from its base (LB in Fig. 6). Besides that, a median saddle-shaped depression of the carapace in the new species is less expressed than in A. jiriensis. The palp of $A$. himalaya sp.n. is also similar to that of the Siberian arcto-boreo-montane A. ripariensis Tanasevitch, 1984. The new species is distinguished by the absence of a tooth at the base of the embolus, as well as by the smaller dorso-retrolateral tooth on the palpal tibia. In addition, the palp of $A$. himalaya sp.n. bears some resemblance to that of $A$. iranica Tanasevitch, 2011, from Golestan, Iran [Tanasevitch, 2011], but the new species differs clearly by a straight apical tooth on the lamella characteristica (vs. clawshaped), and by the absence of a tooth at the base of the embolus (vs. a large tooth).

DESCRIPTION. Male holotype. Dark-coloured specimen. Total length 1.65 (paratype 1.58). Carapace 0.75 long, 0.60 wide, blackish brown. Median saddleshaped depression of carapace indistinct. Chelicerae 0.30 long, weak. Legs grey-brown. Leg I, 2.36 long $(0.60+0.20+0.58+0.53+0.45) ; \mathrm{IV}, 2.40$ long $(0.68+0.18+0.63+0.53+0.38)$. Chaetotaxy: each tibia with two spines, a prolateral spine on tibia I absent. Metatarsus I-III with a trichobothrium. TmI, 0.27. Palp (Figs 1-7): tibia short, with a small apical denticle retrolaterally. Cymbium without distinct conical elevation. Paracymbium simple, anterior pocket larger than posterior one. Main branch of lamella characteristica a long, apically pointed ribbon; lower branch short, narrow, slightly curved. Embolus without teeth basally. Abdomen 0.95 long, 0.75 wide, dark grey, almost black.

Female unknown.

DISTRIBUTION. Known from the highlands of the Himalayas in the Panchthar and Taplejung districts of Nepal.

Erigone jammu sp.n. 


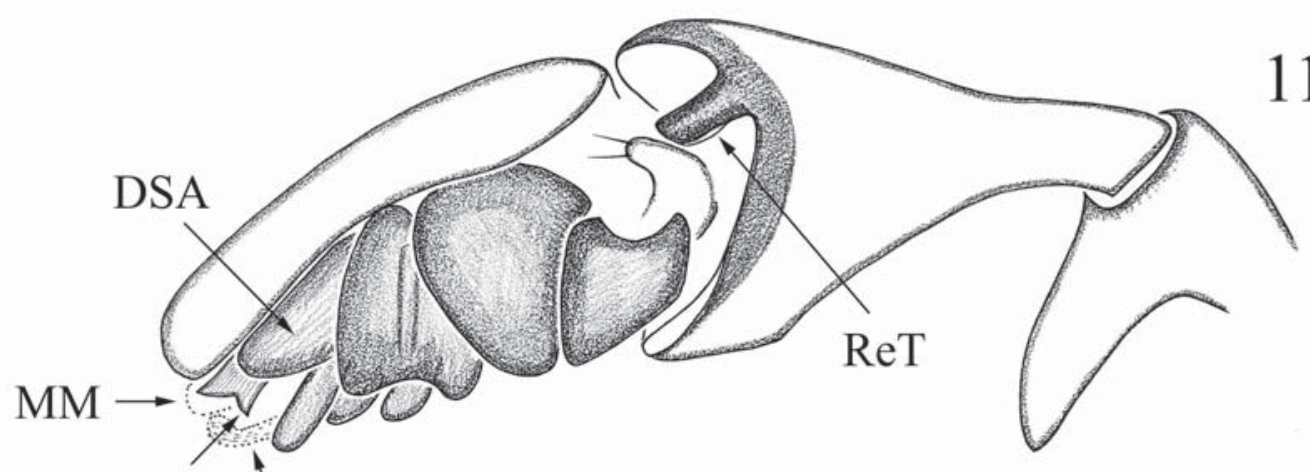

EP

EM
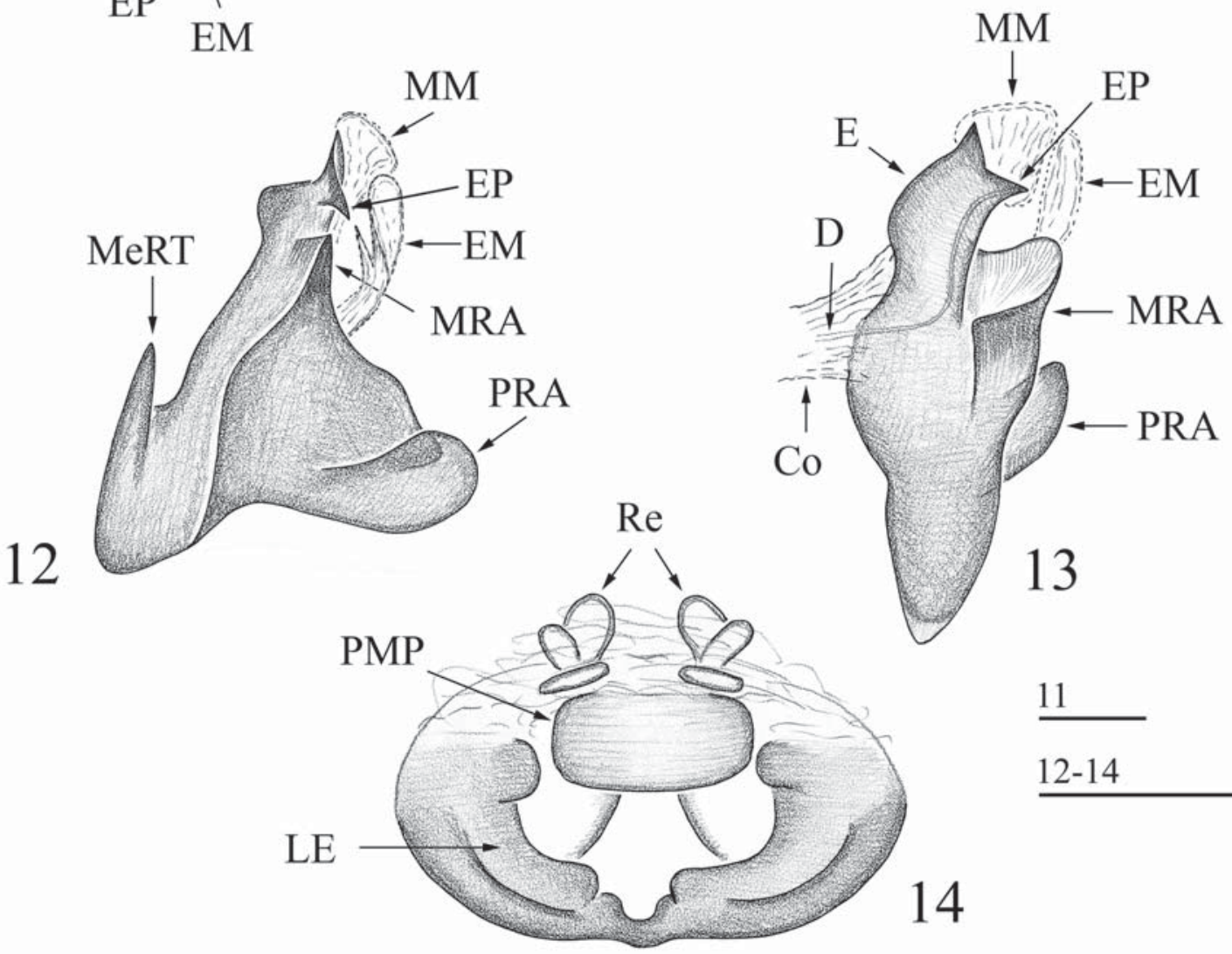

$12-14$

Figs 11-14. Details of palpal and epigynal structure of Erigone jammu sp.n. 11 - left palp; 12, 13 - embolic division, different aspects; 14 - epigyne, dorsal view.

Рис. 11-14. Детали строения пальпы и эпигины Erigone jатmи sp.n. 11- левая пальпа; 12, 13 - эмболюсный отдел, различные аспекты; 14 - эпигина, вид сверху.

Figs 8-14.

HOLOTYPE: $O^{7}$ (SMF, labeled as Erigone sp. by K. Thaler), INDIA, Jammu and Kashmir State, Leh District, Shey, 2.VI.1976, leg. J. Martens.

PARATYPES: $1 \sigma^{7}, 1$ (separated epigyne only) (SMF, labeled as Erigone sp. by K. Thaler), collected together with holotype.

NAME. The species name is a noun in apposition, referring to provenance.

DIAGNOSIS. The new species is most similar to the Palaearctic arcto-alpine E. remota L. Koch, 1869 and the nival E. lata Song et Li, 2008, the latter species described from the Hengduan Mts, China. Erigone jam$m u$ sp.n. can easily be distinguished from both above congeners by the longer, solid, retrolateral tooth on the palpal tibia (vs. shorter and bifid); by the shorter posterior radical apophysis, and the poorly-expressed median apophysis in the embolic division. The female of $E$. jammu sp.n. differs from these two species by the connivent receptacles and the wider lateral edges of the epigyne. The new species also resembles E. rohtangensis Tikader, 1981, this being known from the high altitudes in Himachal Pradesh, India [Tikader, 1981], but differs by the longer retrolateral tibial tooth, the 
narrower posterior median plate of the epigyne, as well as by the receptacles inclined to each other (vs. diverging).

DESCRIPTION. Male paratype. Total length 2.55. Carapace modified as shown in Fig. 8; 1.18 long, 0.90 wide, reddish brown, with teeth at its edge. Chelicerae strong, 0.63. long, with 5-6 teeth on its anterolateral surface, mastidion absent. Legs pale brown. Leg I, 3.10 long $(0.85+0.30+0.75+0.70+0.50), \mathrm{IV}, 2.98$ long $(0.80+0.25+0.75+0.70+0.48)$. Chaetotaxy 2.2.2.1, length of spines 1-1.5 diameters of segment. TmI, 0.40. Metatarsus IV without trichobothrium. Palp (Figs 11-13): patella with a ventro-apical, conical, slightly curved outgrowth. Palpal tibia elongated, with a retrolateral tooth apically. Paracymbium with a well-developed distal part. Distal suprategular apophysis relatively long and wide, rounded distally. Radix with three radical extentions: posterior radical apophysis short, thick, rounded; mesal radical tooth strong, stylet-shaped; median radical apophysis slightly curved, pocketshaped. Embolic membrane relatively short, slightly curved. Embolus proper small, dentiform. Abdomen 0.90 long, 0.63 wide, dark grey.

Female. Epigyne only available. Epigyne (Figs 9, $10,14)$ wide, oval, with wide lateral edges. Posterior median plate wide and short. Receptacles small, inclined to each other.

ACKNOWLEDGEMENTS. I am most grateful to Jochen Martens (Mainz, Germany) who provided the material he collected during his expeditions in the Himalayas, as well as to Peter Jäger and Julia Altmann (SMF), who supplied me with the samples under their care. Thanks go to Sergei Golovatch, who kindly checked the English of an advanced draft.

\section{References}

Caporiacco L. di. 1935. Aracnidi dell'Himalaia e del Karakoram, raccolti dalla Missione italiana al Karakoram (1929-VII) // Memorie della Società Entomologica Italiana, Genova. Vol.13. P.161-263.

Crosby C.R., Bishop S.C. 1928. Revision of the spider genera Erigone, Eperigone and Catabrithorax (Erigoneae) // New York State Museum Bulletin. No.278. P.1-73.

Helsdingen P.J. van. 1965. Sexual behaviour of Lepthyphantes leprosus (Ohlert) (Araneida, Linyphiidae), with notes on the function of the genital organs // Zoologische Mededelingen. Bd.41. S.15-42.

Helsdingen P.J. van. 1986. World distribution of Linyphiidae // Eberhard W.E., Lubin Y.D., Robinson B.C. (eds). Proceedings of the Ninth International Congress of Arachnology, Panama 1983. Washington D.C.: Smithsonian Institution Press. P.121126.

Helsdingen P.J. van, Thaler K., Deltshev C. 1977. The tenuis group of Lepthyphantes Menge (Araneae, Linyphiidae) // Tijdschrift voor Entomologie. Vol.120. P.1-54.

Hormiga G. 1994. Cladistics and the comparative morphology of linyphiid spiders and their relatives (Araneae, Araneoidea, Linyphiidae) // Zoological Journal of the Linnean Society. Vol.111. P.1-71.

Hormiga G. 2000. Higher level phylogenetics of erigonine spiders (Araneae, Linyphiidae, Erigoninae) // Smithsonian Contributions to Zoology. Vol.609. P.1-160.

Merrett P. 1963. The palpus of male spiders of the family Linyphiidae // Proceedings of the Zoological Society of London. Vol.140. P.347-467.

Pickard-Cambridge O. 1885. Sci. Res. Second Yarkand Mission. Araneidea. Calcutta: Superintendent of Government Printing, India. P.1-115, P1.I-II.

Saaristo M.I. 1971. Revision of the genus Maro O. P.-Cambridge (Araneae, Linyphiidae) // Annales Zoologici Fennici. Vol.8. P.463-482.

Saaristo M.I. 1973. Taxonomical analysis of the type-species of Agyneta, Anomalaria, Meioneta, Aprolagus, and Syedrula (Araneae, Linyphiidae) // Annales Zoologici Fennici. Vol.10. P.451466.

Saaristo M.I., Tanasevitch A.V. 1996. Redelimitation of the subfamily Micronetinae Hull, 1920 and the genus Lepthyphantes Menge, 1866 with descriptions of some new genera (Aranei, Linyphiidae) // Berichte des Naturwissenschaftlich-Medizinischen Vereins in Innsbruck. Bd.83. S.163-186.

Tanasevitch A.V. 2011. Linyphiid spiders (Araneae, Linyphiidae) from Pakistan and India // Revue suisse de Zoologie. T.118. P.561-598.

Tanasevitch A.V. 2017. New species and new records of linyphiid spiders from the Indo-Malayan Region (Araneae: Linyphiidae) // Zootaxa. Vol.4227. No.3. P.325-346.

Tikader B.K. 1981. A new species of high altitude spider of the genus Erigone Audouin (Family: Erigonidae) from India // Journal of the Bombay Natural History Society. Vol.77. P.490492.

Wunderlich J. 1983. Linyphiidae aus Nepal, IV. Bisher unbekannte und für Nepal neue Arten (Arachnida: Araneae) // Senckenbergiana Biologica. Bd.63. S.219-248.

Responsible editor K.G. Mikhailov 